\section{Dead trees tell tales}

\author{
Stanley N. Williams
}

MOUNTAINS can be dangerous places, and on page 675 of this issue ${ }^{1}$ Farrar and colleagues describe a hitherto neglected way in which they can kill. Their subject is Mammoth Mountain, in the east of California, a volcano that was last active several hundred years ago and is part of a larger volcanic basin known as the Long Valley caldera. Areas of dead and dying trees occur on Mammoth Mountain. The cause of death has been a mystery but Farrar et al. provide the answer - the trees are being killed by large volumes of carbon dioxide being emitted through the soil from magma deep within the mountain.

Long Valley is a busy recreational centre, Mammoth Mountain being a popular skiing resort because of the deep snow that accumulates on this eastern margin of the Sierra Nevada mountain chain. The dying trees near public camping areas, as well as the cases of near asphyxia in confined spaces that have occurred, have led to an upsurge in concern for "What might happen?". For all that the cause of the tree deaths is now known, the answer to that bigger question will remain elusive.

Events at Mammoth Mountain remind us that calderas such as Long Valley are not only big but complex, and that we don't understand how the voluminous eruptions that cause them actually begin. The reason is basically that we have no good historical examples of large-volume eruptions. Mount St Helens in Washington state was doing its thing in May 1980 when Long Valley began to shake, with several magnitude 5 tectonic earthquakes on the regional faults that cross the caldera. But the eruption that produced Long Valley some 760,000 years ago was about $500 \mathrm{~km}^{3}$ in volume, whereas that at Mount St Helens was only about $1 \mathrm{~km}^{3}$.

Elsewhere in the world, other calderas were almost simultaneously rumbling in the mid-1980s - Campi Flegrei, for example, which is next to the 11 million people of Naples, and Rabaul caldera, in which sits the important harbour of Rabaul in Papua New Guinea. Two neighbouring volcanoes finally erupted in Rabaul ${ }^{2}$ during September-October 1994, after it had first shown signs of unrest in 1971 and significant activity in late 1983 through to mid-1985. Although the eruption was not of a scale even equal to that of Mount St Helens, it was enough to destroy many of the harbour buildings and homes, reminding us of how destructive caldera eruptions can be.

After the 1980 earthquakes in Long Valley, it was found that the caldera had swollen, producing uplift of the central area by up to $75 \mathrm{~cm}$, and the seismicity was interpreted to be related to magmatic resurgence beneath the area ${ }^{3}$. Eventually, those studying the deformation and seismicity produced a model of small dyke injections beneath the south-central moat of the large caldera ${ }^{4}$; and the soil gases mercury and radon were found to be anomalous by an order of magnitude over the area of the dyke, even though the dyke was still at a depth of $3 \mathrm{~km}$ (ref. 5).

Long Valley, however, is really a mixture of three different types and scales of

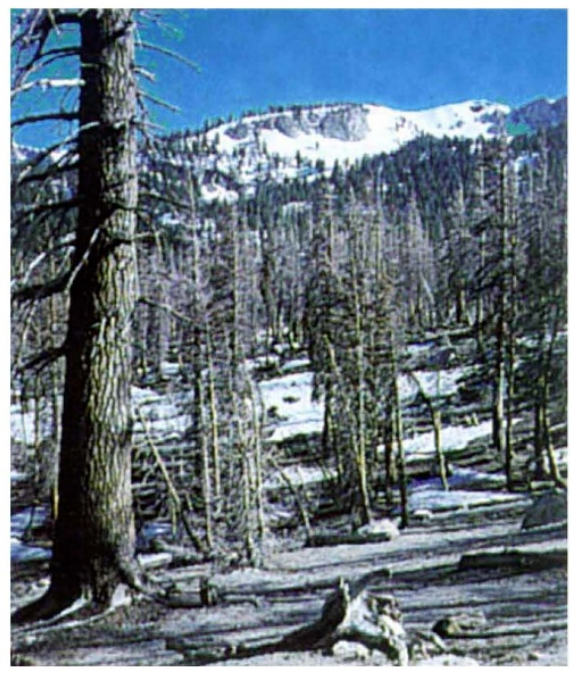

Study in brown at Mammoth Mountain

volcanic feature (see map on page 675) the caldera itself, the Inyo volcanic chain and Mammoth Mountain itself. We have all concentrated on the large-scale feature, with only a little work being done on the small young craters ${ }^{6}$ and almost none on Mammoth Mountain, even though it is a young volcano that has experienced an extended period of activity ${ }^{6.7}$. A summary ${ }^{8}$ of the tectonic and magmatic processes of Long Valley and the associated 12 papers published in 1990 did not discuss the possible involvement of Mammoth Mountain in potential future eruptions. There were, to be fair, good reasons for that. The wilderness behind the mountain makes placement of seismic stations difficult; the snow means that studies of soil gas and deformation are terribly limited; and it was the one part of the caldera complex which seemed to be least active. So, the intense research and modelling of what was producing the activity at Long Valley rather ignored Mammoth Mountain.

Volcanic gases are useful as signals of reactivation of volcanoes because they are so mobile; for instance, Nevada del Ruiz
(Colombia), Redoubt (Alaska) and Pinatubo (Philippines) all showed visible changes in gas emissions for many months before there were significant seismic or deformation signals. Studies of the ideal stable gas, helium, have shown that gases may be moving through the volcanic edifice at several tens of metres a day ${ }^{8}$. Farrar and colleagues ${ }^{1}$ find that carbon dioxide, the other not-highly-reactive gas, is not only killing trees but is advancing as a soil-gas 'halo' in advance of the obvious tree death or stress.

The gases are waving flags at scientists and, more importantly, the people who live or work near the activity. Sorey and others ${ }^{9}$ found strong gas evidence of magmatic activity beneath Mammoth Mountain, which was shown ${ }^{10}$ to be consistent with deformation once new stations had been added to Long Valley, with Mammoth Mountain as the centre of interest. (Our own investigations ${ }^{5}$ of soil gas, carried out in 1983, indicated that Mammoth Mountain was interesting but the unusually heavy snowfall of that year made a complete survey impossible and tricked us into not returning to the volcano.) All concerned should bear in mind that Mammoth Mountain did have small explosive events as recently as $500 \pm 200$ years ago ${ }^{6}$.

Etna and other volcanoes have also been studied for soil-gas emissions of carbon dioxide ${ }^{11}$. The work on Etna, like the study by Farrar et al., convincingly uses carbon isotopes to confirm that magma is the source of the diffuse soil gases. At Etna, it was found that emissions are of a magnitude that is almost equal to that of the gases that pour forth from the very persistently active, main-crater fumaroles and produce the large plumes. Volcanic activity is not so obvious at Mammoth Mountain, but Farrar et al. estimate that 1,200 tons of carbon dioxide are being released each day - that's just about equal to the flux found at other classically active volcanoes, such as Kilauea in Hawaii, which have open crater vents to facilitate gas release. An active magma source is sending out signals from deep beneath Mammoth Mountain, and we must give it much more attention.

Stanley N. Williams is in the Department of Geology, Arizona State University, Tempe, Arizona 85287, USA.

\footnotetext{
. Farrar, C. D. et al. Nature 376, 675-678(1995)

2. Williams, S. N. Science 267, 340-341 (1995).

3. Savage, J. C. \& Clark. M. M. Science 217, 531-533 (1982).

4. Castle, R. O., Estrem, J. E. \& Savage. J. D. J. geophys.

Res. 89, 11507-11516 (1984).

5. Williams, S. N. Science 229, 551-553 (1985)

6. Miller, C. D. Geology 13, 14-17 (1985).

7. Bailey, R. A. Map I-1933 (US Geol. Surv., 1989)

8. Sano, Y., Wakita, H. \& Williams, S. N. J. volcan. geotherm. Res. 42, 41-52 (1990).

9. Sorey, M. L. et al. J. Geophys. Res. 98, 15871 (1993). 10. Langbein, J. O., Hill, D. P., Parker, T. N. \& Wilkinson, S. K. J. geophys. Res. 98, 15851-15870 (1993). 11. Allard, P. et al. Nature 351, 387-391 (1991).
} 